\title{
ANALIZA PRODUKTIVNOSTI AUTORA SVEUČILIŠTA JOSIPA JURJA STROSSMAYERA U OSIJEKU U RAZDOBLJU OD 2011. DO 2015. GODINE
}

\section{PRODUCTIVITY ANALYSIS OF AUTHORS \\ FROM JOSIP JURAJ STROSSMAYER UNIVERSITY IN OSIJEK FOR THE PERIOD FROM 2011 TO 2015}

Ivana Šuvak-Pirić,

Prehrambeno-tehnološki fakultet Osijek

Sveučilište Josipa Jurja Strossmayera u Osijeku isuvak@ptfos.hr

Iva Arači

Odjel za kemiju

Sveučilište Josipa Jurja Strossmayera u Osijeku iva.araci@gmail.com

Mirna Šušak Lukačević

Odjel za matematiku

Sveučilište Josipa Jurja Strossmayera u Osijeku msusak@mathos.hr

Svjetlana Mokriš

Gradska i sveučilišna knjižnica Osijek

marendic@gskos.hr

Sanda Hasenay

Prehrambeno-tehnološki fakultet Osijek

Sveučilište Josipa Jurja Strossmayera u Osijeku hasenays@ptfos.hr

UDK / UDC

025.12:005:001"2011/2015"(497.5 OSIJEK)

Stručni rad / Professional paper

Prihvaćeno / Accepted: 26. 5. 2017.

Vjesnik bibliotekara Hrvatske 60, 1(2017), 243-260

ISSN 0507-1925

(C) VBH 2017. 


\section{Sažetak}

U ovom radu prikazana je produktivnost autora Sveučilišta Josipa Jurja Strossmayera u Osijeku za razdoblje od 2011. do 2015. godine upotrebom bibliometrijskih pokazatelja kroz skup baza podataka Web of Science Core Collection (WoS CC). U analizi su kao osnova uzeti u obzir svi rezultati dobiveni pretragom po adresi Sveučilišta i svake pojedine sastavnice Sveučilišta. Analiza je napravljena prema određenim bibliometrijskim pokazateljima: broju objavljenih radova po sastavnici, njihovoj citiranosti te po h-indeksu sastavnice za navedeno razdoblje, broju objavljenih radova u pojedinoj godini, vrsti dokumenta, znanstvenom području koje pokriva pojedina WoS CC-kategorija, broju radova objavljenih u hrvatskim ili inozemnim časopisima, broju radova objavljenih u zbornicima radova koji su indeksirani u WoS CC te po kvartilu časopisa.

Ključne riječi: bibliometrija, znanstvena produktivnost, autori, Sveučilište Josipa Jurja Strossmayera u Osijeku

\section{Summary}

The paper presents the assessment of productivity of the authors from the University of Josip Juraj Strossmayer in Osijek for the period from 2011 to 2015 using the bibliometric parameters in the Web of Science Core Collection (WoS CC) database. The results were obtained by conducting a research in which the University address and the addresses of all the University units were used as search criteria. The analysis was made according to the following specific bibliometric parameters: the number of published papers per University unit, their citation rates, University units h-index for the given period, the number of published papers per year, the type of papers, scientific fields covered by specific WoS CC categories, number of papers published in domestic or foreign journals, number of papers published in Conference proceedings indexed in WoS CC, and the journal quartile ranking within its subject categories.

Keywords: bibliometrics, scientific productivity, scientists, University of Josip Juraj Strossmayer in Osijek

\section{Uvod}

Znanstvena aktivnost definira se kao javna aktivnost pojedinaca unutar društva okupljenih u znanstvenoj zajednici. ${ }^{1}$ Tijekom svog znanstvenog djelovanja znanstvenici otkrivaju nove činjenice, dolaze do inovacija i generiraju mnoštvo novih informacija koje oblikuju i prezentiraju kroz znanstvenu komunikaciju. Znanstve-

\footnotetext{
1 Vrana, Radovan. Vrednovanje znanstvenog rada. // Vjesnik bibliotekara Hrvatske 54, 1-2(2011), str. 173. Dostupno i na http://hrcak.srce.hr/index.php?show=clanak\&id_clanak_jezik=119700 [citirano: 2017-05-03].
} 
no komuniciranje stoga se definira kao dinamičan sustav čiji su elementi utkani $\mathrm{u}$ neprekinuti niz aktivnosti koje za cilj imaju prijenos znanstvenih informacija $u$ znanstvenoj zajednici i izvan nje te ima presudnu ulogu u napretku znanosti. ${ }^{2}$ Svrha istoga jest da se omogući komuniciranje znanstvenih informacija sa srodnim informacijama prethodnih i sličnih istraživanja ${ }^{3}$ te da se omogući nastavak istraživanja i napredak znanosti na temeljima već istraženog. Za prijenos znanstvenih informacija kao oblik formalne znanstvene komunikacije, danas podjednako u tiskanom i/ ili elektroničnom okruženju, pokazao se časopis.

$\mathrm{Na}$ časopise su se pretplaćivale znanstvene knjižnice diljem svijeta nudeći svojim korisnicima svježe informacije, podupirući na taj način napredak znanosti. Znanstveni časopisi imaju provjeren sustav potvrde kvalitete znanstvenih radova, a time i samih znanstvenika, već stoljećima. Rad objavljen u eminentnom znanstvenom časopisu ima potvrdu vjerodostojnosti svojih znanstvenih spoznaja i jamstvo značajnosti i kvalitete. Autori shvaćaju koliko je važna kvalitetna interpretacija istraživačkih rezultata putem znanstvenih publikacija među kojima je najzastupljenija vrsta publikacija bio i ostao časopis. ${ }^{4}$ Zato autori streme objavljivanju što većeg broja radova u priznatim znanstvenim časopisima, što ujedno njima samima osigurava stabilnu karijeru i priznanje od strane znanstvene zajednice. Autori Macan i Petrak navode da znanstveni časopisi imaju znatnu ulogu i u provođenju znanstvene politike, odnosno u odlučivanju u znanosti jer vrijednosna prosudba časopisa u znanstvenoj zajednici može utjecati na odluke o financijskoj potpori znanstvenim projektima, na rangiranje akademske i znanstvene ustanove te na napredovanje pojedinaca u znanstvenome i akademskom sustavu. ${ }^{5}$

Prve indeksne publikacije koje su donosile informacije o radovima koji su izašli u određenim brojevima časopisa različitih izdavača pojavile su se kako bi se što lakše i jednostavnije moglo doći do informacija iz određenog znanstvenog područja s obzirom na veliki broj časopisa. Indeksna publikacija Current Contents izdavača Institute for Scientific Information iz Philadelphie bila je jedna od takvih publikacija i donosila je sadržaje niza časopisa znatno prije negoli su se isti pojavili u knjižnicama. ${ }^{6}$ Isti izdavač objavio je i Science Citation Index koji je, osim bibliografskih podataka, donosio i podatke o citiranosti radova. 1992. godine, nakon što je autorska prava za ove indeksne publikacije preuzela tvrtka Thomson

\footnotetext{
2 Isto, str. 172.

3 Isto, str. 172-173.

4 Stojanovski, Jadranka. (R)evolucija znanstvenih časopisa. // Hrvatski znanstveni časopisi : iskustva, gledišta, mogućnosti / ur. Ivana Hebrang Grgić. Zagreb : Školska knjiga, 2015. Str. 55.

5 Macan, Bojan; Jelka Petrak. Bibloimetrijski pokazatelji za procjenu kvalitete znanstvenih časopisa. // Hrvatski znanstveni časopisi : iskustva, gledišta, mogućnosti / ur. Ivana Hebrang Grgić. Zagreb : Školska knjiga, 2015. Str. 37.

6 Stojanovski, Jadranka. Metrika znanstvene publicistike - istina, mitovi i zablude. // Kemija u industriji 59, 4 (2010), 179. Dostupno i na http://hrcak.srce.hr/index.php?show=clanak\&id_clanak_jezik=77493 [citirano: 2017-05-03].
} 
(kasnije Thomson Reuters, a od jeseni 2016. Clarivate Analytics), dobile su formu baza podataka. ${ }^{7}$ Biti prisutan u navedenim indeksnim publikacijama, a kasnije i bazama podataka, znak je kvalitete časopisa. Clarivate Analytics danas je jedna od najvećih svjetskih tvrtki koje se bave analizama znanstvenih i akademskih istraživanja, patentima i pravnim standardima, inovacijama u farmaciji i biotehnologiji, upravljanjem intelektualnim vlasništvom i zaštitnim znakovima. ${ }^{8}$

Pojavom baza podataka u mrežnom okruženju nametnula se potreba za bibliometrijskim istraživanjima u svakodnevnom poslovanju u svrhu potpore znanstvenom radu. Multidisciplinarne baze podataka transparentno prikazuju znanstvenu produktivnost autora, a akademski su knjižničari sukladno tomu prepoznali potrebu da se dokažu u svijetu znanosti kroz evidencije znanstvene produktivnosti. Kako navode Corrall i sur., stručnost knjižničara može biti upotrijebljena kao pomoć autorima na fakultetu u njihovu znanstvenom napredovanju. ${ }^{9} \mathrm{U}$ knjižnično je poslovanje stoga uključena usluga pretrage indeksiranosti i citiranosti pojedinih autora u svrhu znanstvenog napredovanja, ali isto tako i bibliometrijskih istraživanja pojedine sastavnice sveučilišta u svrhu višegodišnjeg financiranja znanstvene djelatnosti. Logičan nastavak toj usluzi jest i ovo istraživanje kojim se nastoji dobiti uvid u znanstvenu produktivnost cjelokupne zajednice na Sveučilištu Josipa Jurja Strossmayera u Osijeku (osječko sveučilište). S obzirom na različita znanstvena područja kojima pripadaju analizirani radovi, u ovom istraživanju nisu se pravile detaljne analize, već su se samo prikazali ukupni rezultati.

Bibliometrijske pokazatelje koji bi objedinili specifične informacije i dovoljno dobro opisali znanstvenu aktivnost ipak nije lako usustaviti budući da, kako kazuje i izvješće International Mathematical Union (IMU), istraživanje obično ima mnoštvo ciljeva, pa je s toga razumno da se njegova vrijednost procjenjuje po više kriterija. ${ }^{10}$

\section{Web of Science Core Collection (WoS CC)}

Web of Science Core Collection ${ }^{11}{ }^{12}$ (prije (ISI) WEB of Knowlege) multidisciplinarni je skup baza podataka koji se sastoji od više citatnih indeksa. Do listopada

\footnotetext{
Isto, str. 179-180.

8 Clarivate Analytics. [citirano: 2017-05-22] Dostupno na http://clarivate.com/about-us/whatwe-do/

9 Corrall, Sheila; Mary Anne Kennan; Waseem Afzal. Bibliometrics and research data management services : emerging trends in library support for research. // Library Trends 61, 3(2013), 636-674.

10 Citation statistics: International Mathematical Union report. 2008. Str. 5 [citirano: 2017-05-

03] Dostupno na http://www.mathunion.org/fileadmin/IMU/Report/CitationStatistics.pdf.

11 Popis publikacija koje WoS CC indeksira dostupan je na http://ip-science.thomsonreuters. $\mathrm{com} / \mathrm{mjl} /$ [citirano: 2017-05-03].

12 Web Of Science Core Collection : descriptive document. 2016. Str. 1 [citirano: 2017-05-23] Dostupno na http://clarivate.libguides.com/ld.php?content_id=29366073
} 
2016. godine WoS CC održavao je Thompson Reuters, a nakon toga Clarivate Analytics. Bibliografske baze podataka sadržavaju bibliografske zapise o nekom objavljenom dokumentu, npr. o članku iz časopisa, kongresnom priopćenju, službenoj publikaciji i sl. Citatne baze podataka tim bibliografskim zapisima dodaju još i podatke o citiranosti. ${ }^{13}$ Multidisciplinarne baze podataka su citatne baze podataka koje u svojim bibliografskim zapisima osim imena autora, naslova članka, podataka o časopisu (naslov, volumen, broj, godina, stranice), ključnih riječi, sažetka, adrese autora i nakladnika sadrže i popis citiranih referenci. Zahvaljujući tome one predstavljaju glavni instrument za vrednovanje časopisa, znanstvene produkcije autora, institucija i zemalja. ${ }^{14}$

Začetnik ideje o elektroničkoj bazi podataka je dr. Eugene Garfield ${ }^{15}$, koji je 1955. godine došao na ideju oblikovanja platforme od oko 600 časopisa. Odabrani časopisi činili su u to vrijeme $5-8 \%$ ukupnog broja znanstvenih časopisa. U to vrijeme baza je nosila ime SCI-Science Citation Index te je i danas jedan dio WoS CC-a. Garfieldovo je postignuće u utvrđivanju korisnosti i objektivnosti indeksa citiranja u povlačenju srodnih radova u objavljenoj literaturi koja se na prvi pogled možda nije činila relevantnom u istraživanju. Danas se smatra jednim od najpouzdanijih resursa u praćenju razvoja ideje kroz mnoštvo disciplina koje su dio znanstvenog znanja. ${ }^{16}$ Tijekom godina u WoS CC su se počeli uvrštavati i časopisi iz društvenih i humanističkih znanosti.

Trenutno su za hrvatsku akademsku zajednicu dostupni sljedeći citatni indeksi: Science Citation Index Expanded (SCI-EXPANDED) (1955. - danas); Social Sciences Citation Index (SSCI) (1955. - danas); Arts \& Humanities Citation Index (A\&HCI) (1975. - danas); Conference Proceedings Citation Index- Science (CPCI-S) (1990. - danas); Conference Proceedings Citation Index- Social Science \& Humanities (CPCI-SSH) (1990. - danas); Book Citation Index- Science (BKCI-S) (2005. - danas); Book Citation Index- Social Sciences \& Humanities (BKCI-SSH) (2005. - danas) i Emerging Sources Citation Index (ESCI) (2015. danas). Tu su i dva kemijska indeksa: Current Chemical Reactions (CCR-EXPANDED) (1985. - danas) i Index Chemicus (IC) (1993. - danas). ${ }^{17}$

\footnotetext{
13 Macan, Bojan; Jelka Petrak. Nav. dj., str. 39.

14 Brajenović Milić, Bojana. Bibliometrijski pokazatelji znanstvenog odjeka autora i časopisa. // Medicina fluminensis 50, 4(2014.), str. 426. Dostupno i na http://hrcak.srce.hr/129784 [citirano: 2017-05-03].

15 In memoriam: dr. Eugene Garfield : September 16, 1925 - February 26, 2017. [citirano: 2017 05-22] Dostupno na http://clarivate.com/dr-garfield/?_ga=1.236437830.616265103.1486463420.

16 History of citation indexing. [citirano: 2017-05-22] Dostupno na http://wokinfo. com/essays/history-of-citation-indexing/?_ga=2.73581585.2047322992.1495455670616265103.1486463420 .

17 Portal elektroničkih izvora za hrvatsku akademsku i znanstvenu zajednicu. [citirano: 2017-0503] Dostupno na http://baze.nsk.hr/baza/web-science/.
} 
U početku su se u citatnim indeksima indeksirali samo izvorni znanstveni članci, a danas se indeksiraju i različiti prilozi kao što su kratka znanstvena priopćenja, konferencijska priopćenja, sažeci sa znanstvenih skupova, prikazi knjiga, ispravci i komentari. U 2016. godini u bazi je indeksirano oko $22900^{18}$ naslova vodećih svjetskih časopisa iz svih područja znanosti, čiji su izdavači akademske i istraživačke ustanove (oko 7000) ${ }^{19}$, razne organizacije i drugi izdavači iz više od 100 zemalja svijeta (kao što su npr. komercijalni izdavači poput Elseviera, Springera, Wileya i sl.).

\section{O bibliometriji}

U poplavi znanstvenih radova i časopisa bilo je potrebno usustaviti metodu kojom bi se popisala, a zatim i opisala obilježja znanstvenih radova te utvrdili odnosi i veze među znanstvenim djelima i bibliografskim entitetima koji nastaju na osnovi raščlambe svojstava dokumenata. ${ }^{20}$ Ta je znanstvena metoda 1969. godine od strane Alana Pritcharda imenovana kao „bibliometrija“ i definirana kao „proučavanje korištenja dokumenata i obrazaca publikacija pomoću matematičkih i statističkih metoda s ciljem poboljšanja znanstvene dokumentacije, informacije i komunikacije“. ${ }^{21}$ Bibliometrijskim pokazateljima, koji su uglavnom standardizirane kvantitativne mjere, nastoji se objasniti, usporediti i razumjeti temeljna obilježja znanosti. ${ }^{22}$ Najpoznatiji bibliometrijski pokazatelji su h-indeks i faktor odjeka (Impact Factor - IF). H-indeks je mjera kojom se prikazuje znanstvena aktivnost istraživača i služi za usporedbu znanstvenika iz istog područja i približno istog radnog iskustva. Jokić ga objašnjava na sljedeći način: „Znanstvenik ima određeni h-indeks ako je svaki od njegovih $\mathrm{N}_{\mathrm{p}}$ radova dobio najmanje $\mathrm{h}$ citata, dok ostalih $\left(\mathrm{N}_{\mathrm{p}}-\mathrm{h}\right)$ radova ima $\leq \mathrm{h}$ citata. To u praksi znači da ako autor ima h-indeks 10 , tada je objavio 10 ili više radova, pri čemu je njegovih 10 radova dobilo najmanje po 10 citata, dok su njegovi ostali radovi citirani manje od deset puta. Ukupan broj citata u ovom slučaju može biti najmanje 100.“23 Faktor odjeka (IF) je broj koji

\footnotetext{
18 Podatak preuzet sa stranica Clarivate Analytics. [citirano: 2017-05-03] Dostupno na http:// ip-science.thomsonreuters.com/cgi-bin/jrnlst/jlresults.cgi?PC=MASTER1.

19 Web of Science. Intelligent results, brilliant connections : brochure. [citirano: 2017-05-03] Dostupno na http://ipscience.thomsonreuters.com/product/web-of-science/.

20 Pehar, Franjo. Od statističke bibliografije do bibliometrije : povijest razvoja kvantitativnog pristupa istraživanju pisane riječi. // Libellarium 3, 1(2010), 3. Dostupno i na http://hrcak.srce.hr/ index.php?show=clanak\&id_clanak_jezik=110191 [citirano: 2017-05-03].

${ }^{21}$ Bibliometrija. // Proleksis enciklopedija. [citirano: 2017-05-03] Dostupno na: http://proleksis. lzmk.hr/11019/.

22 Pehar, Franjo. Nav. dj., str. 15.

23 Jokić, Maja. H-indeks kao novi scientometrijski indikator. // Biochemia medica 19, 1(2009),

6. Dostupno i na http://hrcak.srce.hr/index.php?show=clanak\&id clanak jezik=51302 [citirano: 2017-05-03].
} 
pokazuje koliko se puta prosječno citira jedan znanstveni rad u nekom časopisu u određenom razdoblju. ${ }^{24}$ Vrijednosti IF-a za svaki pojedini časopis jednom godišnje objavljuju se u Journal Citation Reportu ${ }^{25}$ (JCR), statističkoj bazi podataka Clarivate Analytics. JCR je snažan alat za analizu znanstvenih časopisa koji omogućuje više načina rangiranja, evaluacije, kategorizacije i komparacije časopisa oslanjanjem na različite citatne pokazatelje. ${ }^{26}$

Kroz analizu i bibliometrijska istraživanja znanstvene aktivnosti mogu se utvrditi sljedeće informacije:

1) obilježja znanstvene zajednice

2) razvoj znanstvene zajednice

3) vrednovanje znanstvenog doprinosa

4) rasprostranjenost ideja unutar različitih disciplina i između njih. ${ }^{27}$

William Paisley predložio je i petu kategoriju u koju su uključena i „demografska pitanja“ kojima bi se istražila i društvena struktura znanosti poput institucijske pripadnosti autora, sadržaja samoga istraživanja i sl. ${ }^{28}$ Iz svega rečenog vidljivo je da je procjena kvalitete znanstvenih radova objavljenih u časopisima kao najvažnijem obliku znanstvene komunikacije od iznimne važnosti ne samo za samog znanstvenika već i za ustanovu s koje dolazi. Kada govorimo o rangiranju ustanova na temelju produktivnosti, ali i rangiranju u znanosti općenito, od presudne je važnosti poznavanje metodologije i izvora korištenih za rangiranje. ${ }^{29}$

\section{Sastavnice Sveučilišta Josipa Jurja Strossmayera}

U sastavu Sveučilišta Josipa Jurja Strossmayera nalazi se 11 fakulteta, 5 sveučilišnih odjela te Umjetnička akademija.

\footnotetext{
24 Brajenović Milić, Bojana. Nav. dj., str. 429.

25 Više o Journal Citation Report vidi na https://jcr.incites.thomsonreuters.com/JCRJournalHomeAction.action?SID=B1-huJ6tI334GdGXKNQtLCYr0x2FZaqsnjoPq-18x2d8JJ5sjNtx2Bnoa4tn0JGiq6Ax3Dx3Df6PQzwz3HOIzH1CI504xx7gx3Dx3D-9vvmzcndpRgQCGPd1c2qPQx3Dx3D-wx2BJQh9GKVmtdJw3700KssQx3Dx3D\&SrcApp=IC2LS\&Init=Yes.

26 Macan, Bojan; Jelka Petrak. Nav. dj., str. 47.

27 Pehar, Franjo. Nav. dj., str. 17.

28 Isto, str. 17.

29 Jokić, Maja; Krešimir Zauder; Srebrenka Letina. Karakteristike hrvatske nacionalne i međunarodne znanstvene produkcije u društveno-humanističkim znanostima i umjetničkom području za razdoblje 1991-2005. Zagreb : Institut za društvena istraživanja, 2012. Str. 15 [citirano: 2017-05-03] Dostupno na http://idiprints.knjiznica.idi.hr/10/1/Karakteristike\%20hrvatske\%20 nacionalne $\% 20 \mathrm{i} \% 20 \mathrm{me} \% \mathrm{C} 4 \% 91$ unarodne $\% 20$ znanstvene $\% 20$ produkcije $\% 20 \mathrm{u} \% 20 \mathrm{dru} \%$ C5\%A1tveno-humanisti\%C4\%8Dkim\%20znanostima\%20i\%20umjetni\%C4\%8Dkom\%20podru\%C4\%8Dju\%20za\%20razdoblje\%201991-2005.pdf.
} 
Sastavnice iz prirodnih, tehničkih, biomedicinskih i biotehničkih znanosti (STEM) su Poljoprivredni fakultet, Građevinski fakultet, Elektrotehnički fakultet, Prehrambeno-tehnološki fakultet, Strojarski fakultet u Slavonskom Brodu, Medicinski fakultet, Odjel za biologiju, Odjel za kemiju, Odjel za matematiku i Odjel za fiziku.

Sastavnice iz društvenih i humanističkih područja te umjetničkih područja (SSHA) su Ekonomski fakultet, Fakultet za odgojne i obrazovne znanosti, Filozofski fakultet, Pravni fakultet, Katolički bogoslovni fakultet u Đakovu, Odjel za kulturologiju te Umjetnička akademija. ${ }^{30}$

\section{Istraživanje}

\subsection{Metodologija}

Za potrebe ovoga rada napravljena je pretraga skupa baza podataka Web of Science Core Collection (WoS CC) po adresi osječkog sveučilišta i svake pojedine sastavnice osječkog sveučilišta (pretraga je provedena uz korištenje svih pronađenih varijacija imena) za razdoblje od 2011. do 2015. godine. Pretraga je provedena 8. i 9. rujna 2016. godine. Preliminarnom pretragom WoS CC-a (provedeno 13.-17. lipnja 2016. godine) samo po adresi osječkog sveučilišta nisu dobiveni potpuni rezultati, a dobilo se oko 1200 rezultata. Nakon analize dobivenih rezultata uočeno je da su osim različitog navođenja naziva osječkog Sveučilišta (Univ JJ Strossmayer Osijek; JJ Strossmayero Univ, Osijek; Univ Osijek, Zagreb, Croatia; Sveuciliste Josipa Jurja Strossmayera Osijeku; Sveucilista Osijeku, JJ Strossmay Osije, ...) u WoS CC unesene i različite varijacije naziva sastavnica (npr.: Sch Med; Fak Med; Univ Med Sch; Schl Med Osijek; Med Univ Osijek; Med Sch; Osijek Med Fac; Med Fac; Med Fak; Mech Engn Fac Slavonski Brod; Fac Mech Engn; Mech Enginnering Fac; Fac Mech Engi; Agron Fak; Poljoprivredni Fak; Fac Agron; Poljoprivredni Fak Sveucilista JJ Strossmay Osije; Landwirtschaftliche Fak; Filozofski Fak; Philosoph Fak Osijek; Fac Philosophy; Fac Human Sci; Dept English Language \& Linguist; Dept English Language \& Literature; Dept Psychol; Gradevinski Fak; Civil Engn Fac Osijek; Dept Civil Engn; Elektrotehn Fak Osijek; Dept Commun; Elektrotehnicki Fak Osijek; Fac Educ; Fac Educ Sci; Fak Odgojne \& Obrazovne Znanosti; Uciteljski Fak; Dept Cultural Studies). Također je uočeno da autori u pojedinim radovima u adresu nisu unijeli naziv Sveučilišta, nego samo naziv sastavnice te se u rujnu pristupilo ponovnoj pretrazi WoS CC-a po adresi osječkog Sveučilišta, ali nakon toga i po adresi svake sastavnice pojedinačno. U pretragu su uključene različite varijacije naziva koje su se pojavile tijekom

30 Vidi: Sveučilište Josipa Jurja Strossmayera u Osijeku: sastavnice. [citirano: 2017-03-05] Dostupno na https://www.unios.hr/o-sveucilistu/sastavnice/. 
probne pretrage kako bi se dobili što točniji rezultati. Iz pretrage su isključeni radovi autora koji su kao adresu naveli Klinički bolnički centar Osijek, odnosno osječku bolnicu.

Istraživanjem su obuhvaćeni autori osječkog sveučilišta, uključujući znanstvenike, znanstvene novake te asistente koji još nisu u zvanju docenta, predavače, više predavače i ostale autore koji dolaze sa sastavnica osječkog sveučilišta.

Hipoteza za rad bila je da je produktivnost autora Sveučilišta Josipa Jurja Strossmayera u Osijeku u stalnom porastu.

Analiza je napravljena prema određenim bibliometrijskim pokazateljima: broju objavljenih radova po sastavnici, njihovoj citiranosti te po h-indeksu sastavnice za navedeno razdoblje, broju objavljenih radova u pojedinoj godini, vrsti dokumenta, znanstvenom području koje pokriva pojedina WoS CC-kategorija, broju radova objavljenih u hrvatskim ili inozemnim časopisima, broju radova objavljenih u zbornicima radova koji su indeksirani u WoS CC-u te po kvartilu časopisa. Dobiveni rezultati obrađeni su kvantitativnom metodom i standardnim statističkim postupcima, a podaci su izraženi prirodnim brojem i postotkom, prikazani grafički te opisani.

\subsection{Rezultati i rasprava}

Analize su se provele kako bi se potvrdila hipoteza da je produktivnost autora Sveučilišta Josipa Jurja Strossmayera u Osijeku u razdoblju od 2011. do 2015. godine u stalnom porastu. Istraživanje o produktivnosti autora hrvatskih sveučilišta proveli su još 2006. godine Jokić i sur. ${ }^{31}$ Također, ako se usporede izvješća za Namjensko financiranje znanstvene djelatnosti ${ }^{32}$ pojedinih sveučilišta, može se utvrditi da je znanstvena produktivnost bila u stalnom porastu. Analizirajući podatke s različitih sveučilišta utvrdilo se da autori iz STEM-područja imaju više publiciranih radova u WoS CC-u nego autori iz društvenih i humanističkih znanosti te s umjetničkog područja.

\footnotetext{
31 Jokić, Maja; Josip Stepanić; Boris Kamenar; Vlatko Silobrčić. Research output of Croatian Universities from 1996 to 2004, registered by the Science citation indeks-expanded. // Interdisciplinary Description of Complex Systems: INDECS 4, 1 (2006), 44-50. [citirano: 2017-05-03] Dostupno na http://hrcak.srce.hr/index.php?show=clanak\&id_clanak_jezik=114125.

32 Npr. Sveučilište u Zagrebu: namjensko financiranje znanstvene djelatnosti. [citirano: 2017 05-03] Dostupno na http://www.unizg.hr/istrazivanje/istrazivanje-i-inovacije/financiranje-istrazivanja/namjensko-visegodisnje-institucijsko-financiranje-znanstvene-djelatnosti/ ; Sveučilište u Dubrovniku: namjensko financiranje znanstvene djelatnosti. [citirano: 2017-05-03] Dostupno na http://www.unidu.hr/odjeli.php?idizbornik=919; Sveučilište u Splitu: namjensko financiranje znanstvene djelatnosti. [citirano: 2017-05-03] Dostupno na http://www.unist.hr/LinkClick.aspx?fileticket=ZdfCFGu2_18\%3d\&tabid=1580\&portalid=0\&mid=2837.
} 


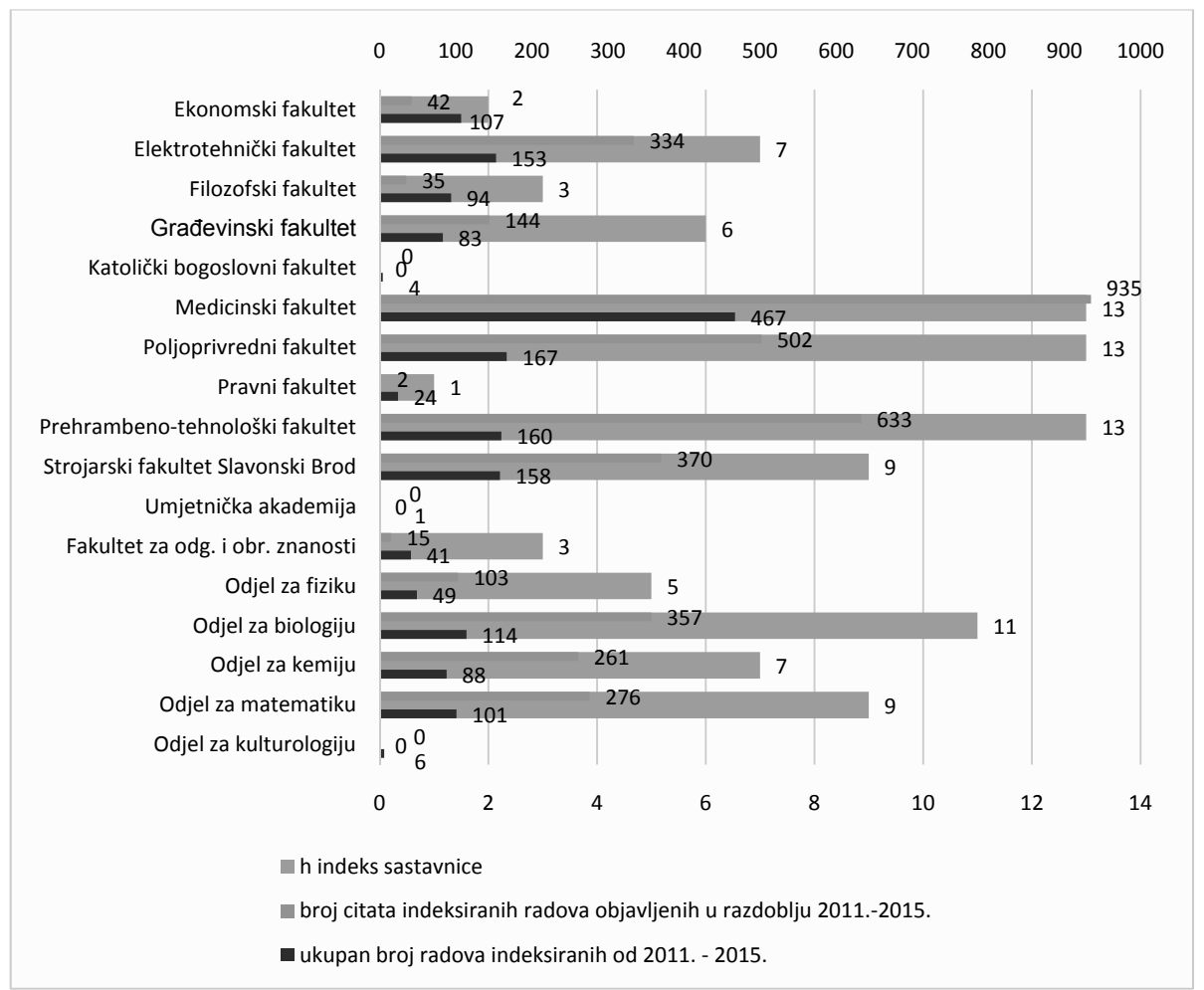

Slika 1. Broj radova po sastavnici, broj citata i h-indeks sastavnice za razdoblje 2011.-2015.

U razdoblju od 2011. do 2015. godine autori Sveučilišta Josipa Jurja Strossmayera u Osijeku objavili su 1817 radova (slika 1). 154 rada nastala suradnjom autora s pojedinih sastavnica Sveučilišta na slici 1 brojala su se svakoj sastavnici kojoj pripada autor na radu, a u daljnjoj analizi brojala su se jednom te se analiza znanstvene produktivnosti na Sveučilištu Josipa Jurja Strossmayera u Osijeku zasniva na 1663 indeksirana rada.

Analizom dobivenih rezultata utvrđeno je da autori iz STEM-područja objavljuju više radova u časopisima koji su indeksirani u WoS CC-u u odnosu na autore iz društvenih i humanističkih područja i umjetničkog područja. To se može pojasniti činjenicom da znanstvene discipline društvenih i humanističkih područja te umjetničkog područja imaju drugačije načine znanstvenog komuniciranja, da časopis u tim disciplinama nije ključni komunikacijski medij te da do 2006. godine WoS CC nije bio mjerilo znanstvene produktivnosti autora iz tih područja. ${ }^{33}$

33 Jokić, Maja; Krešimir Zauder; Srebrenka Letina. Nav. dj., str. 27. 
Jednako tako, radovi znanstvenika sa sastavnica koje pokrivaju STEM-područja imaju više citata te sastavnice tih područja imaju i viši h-indeks. H-indeks je broj koji kazuje da su radovi s adresom sastavnice citirani h puta ili više. Najviše radova objavili su znanstvenici Medicinskog fakulteta (467 radova). Medicinski fakultet ima i najvišu citiranost radova ( 935 citata). U ovom istraživanju utvrdilo se da je najviši h-indeks za analizirano razdoblje za sastavnicu 13 te da ga imaju tri sastavnice: Medicinski, Poljoprivredni i Prehrambeno-tehnološki fakultet.
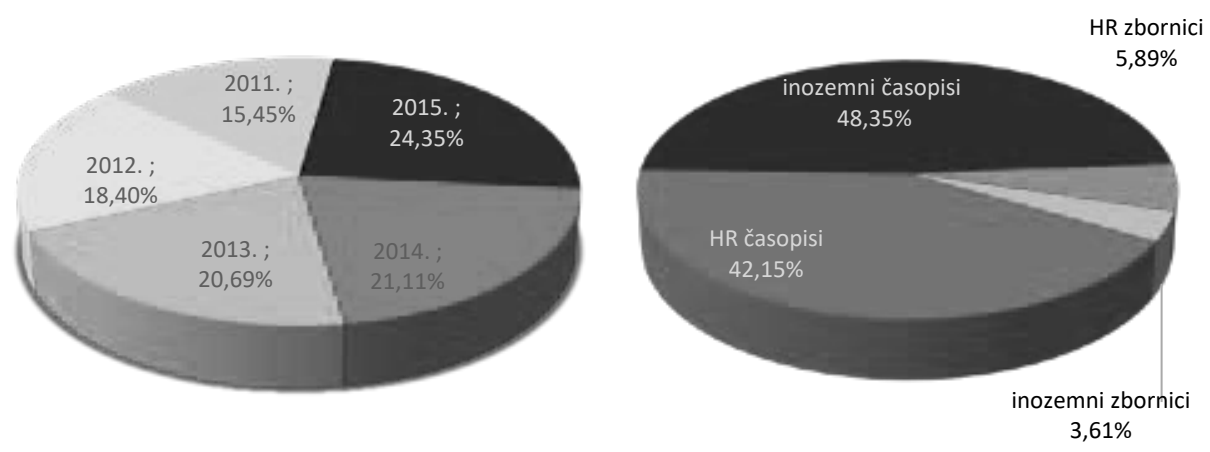

Slika 2. Broj radova po godini objave rada te hrvatski i inozemni časopisi i zbornici u kojima su radovi objavljeni prikazani u \% (2011.-2015.)

Analiza objavljenih radova po godinama objavljivanja pokazuje stalni rast broja objavljenih radova. 2011. godine objavljeno je 15,45\% (257 radova) od ukupnog broja objavljenih radova u razdoblju od 2011. do 2015., dok je 2015. broj objavljenih radova porastao na 24,35\% (405 radova) (slika 2). Autori s osječkog sveučilišta više objavljuju u inozemnim časopisima indeksiranim u WoS CC-u (45,13\%) nego u hrvatskim (40,78\%), što ne čudi s obzirom na zastupljenost hrvatskih časopisa u odnosu na inozemne. WoS CC ukupno indeksira 22926 $^{34}$ časopisa (travanj 2017.), od kojih su 53 hrvatska časopisa. ${ }^{35}$ Analizom radova iz zbornika sa skupova koje indeksira WoS CC utvrđeno je da su autori više objavljivali radove u zbornicima sa skupova čiji su organizatori iz Republike Hrvatske nego u inozemnim zbornicima, što ukazuje na veću posjećenost hrvatskih skupova.

34 Podatak preuzet sa stranice Clarivate Analytics : Master Journal List - Journal List [citirano: 2017-05-03] Dostupno na http://ip-science.thomsonreuters.com/cgi-bin/jrnlst/jlresults.cgi?PC=MASTER.

35 Stojanovski, Jadranka. Hrvatski časopisi u WoS CC, CC, JCR i Scopus bazama podataka za 2015. [citirano: 2017-05-03] Dostupno na https://lib.irb.hr/web/hr/vijesti/item/1893-croatian_journals_wos_cc_scopus_databases_2015.html. 


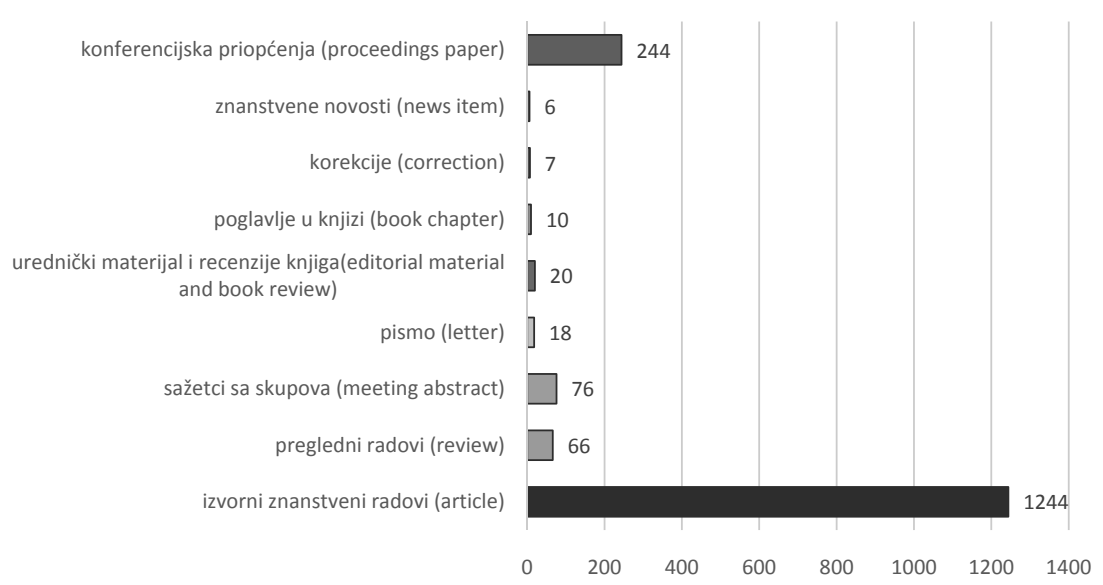

Slika 3. Objavljeni radovi indeksirani u bazi podataka WoS CC za razdoblje 2011.-2015.

Analiza po vrsti rada (slika 3) pokazuje da su znanstvenici u razdoblju od 2011. do 2015. godine najviše objavljivali izvorne znanstvene radove (1244), potom konferencijska priopćenja (244), pregledne radove (66), sažetke sa skupova (76), uredničke materijale i recenzije knjiga (20), znanstvena pisma (18), poglavlja u knjizi (10) i korekcije (7), dok je objavljeno najmanje znanstvenih novosti (7). Analiza pokazuje da znanstvenici rezultate svojih istraživanja najviše prezentiraju u obliku znanstvenog rada u časopisu te zborniku radova sa skupova.

\section{Radovi objavljeni u hrvatskim i inozemnim časopisima i zbornicima radova}

Autori sa Sveučilišta Josipa Jurja Strossmayera u Osijeku više radova publicirali su u inozemnim nego u hrvatskim časopisima, što se može objasniti shvaćanjem znanstvenika o (važnosti) jačini odjeka objave vlastitih istraživanja u prestižnim inozemnim časopisima koji su dostupni znanstvenicima cijelog svijeta, a zastupljeni su u relevantnim bazama podataka, kao i prethodno utvrđenom činjenicom da autori iz STEM-područja rezultate dobivene istraživanjima više objavljuju u časopisima. Citatna baza Journal Citation Reports (JCR) svrstala je časopise pojedinih predmetnih kategorija u kvartile (Q1-Q4) prema visini faktora odjeka. Drugim riječima, ako neki časopis pripada prvom kvartilu (Q1), to znači da on prema visini svojeg faktora odjeka pripada među $25 \%$ časopisa s najvišim faktorom odjeka unutar skupine časopisa koji su svrstani u to predmetno područje. ${ }^{36} \mathrm{Iz}$ razloga što se časopisi različitih kategorija ne mogu, i ne trebaju, uspoređivati, ovu analizu treba gledati samo kao općenit prikaz časopisa razvrstanih po kvartilima koje preferiraju autori osječkog sveučilišta prilikom objave svojih rezultata.

36 Macan, Bojan; Jelka Petrak. Nav. dj., str. 48-49. 
HR časopisi razvrstani po kvartilima

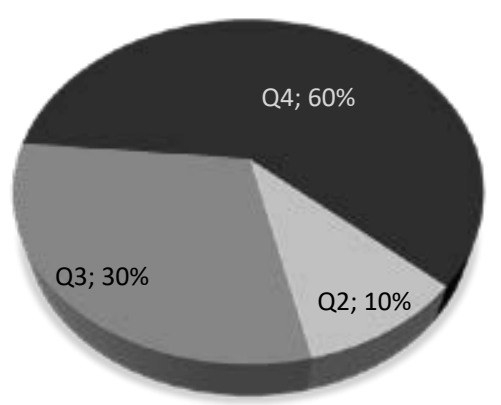

Inozemni časopisi razvrstani po kvartilima

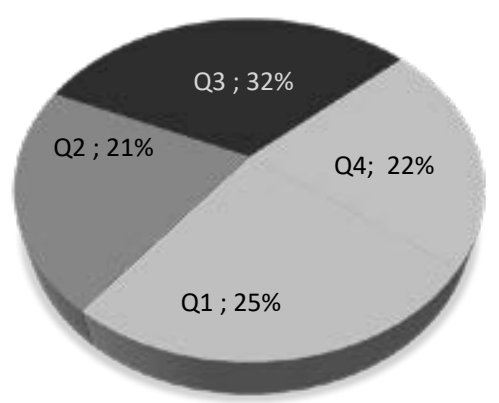

Slika 4. Broj radova objavljenih u hrvatskim i inozemnim časopisima razvrstan po kvartilima časopisa

U radu su analizirani radovi objavljeni posebno u hrvatskim, a posebno u inozemnim časopisima s obzirom na kvartile časopisa u predmetnom području (slika 4). Radova objavljenih u hrvatskim časopisima u prvom kvartilu nema. 10\% radova objavljeno je u časopisima u drugom kvartilu, 30\% radova u trećem kvartilu, a najviše radova, $60 \%$, objavljeno je u časopisima koji pripadaju četvrtom kvartilu. Ovom analizom potvrdilo se da mnogi hrvatski autori ne samo da ne publiciraju svoja istraživanja u hrvatskim časopisima već ni ne citiraju objavljene radove u hrvatskim časopisima. Citiranje radova objavljenih u hrvatskim časopisima važno je jer bi se jedino na taj način povećao broj citata pojedinog hrvatskog časopisa, a time bi rastao i ugled časopisa u znanstvenom okruženju te bi časopis prešao u viši kvartil.

Analiza objavljenih radova u inozemnim časopisima pokazuje da su autori osječkog sveučilišta objavili $25 \%$ radova u časopisima u prvom kvartilu, $21 \%$ u drugom, u trećem ih je bilo $32 \%$, a $22 \%$ radova objavljeno je u časopisima koji pripadaju četvrtom kvartilu.

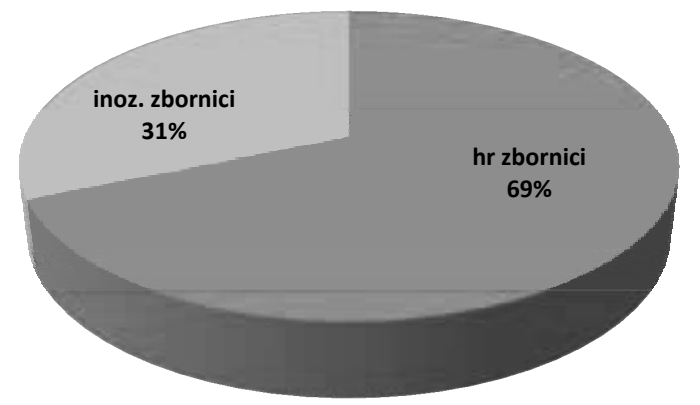

Slika 5. Broj radova objavljenih u hrvatskim i inozemnim zbornicima radova 
Od ukupnog broja objavljenih radova 9,5\% su konferencijska priopćenja. U zbornicima čiji je jedan od organizatora kongresa iz Republike Hrvatske autori su objavili 69\%, dok je 75 konferencijskih priopćenja (31\%) objavljeno u zbornicima čiji su organizatori kongresa iz drugih zemalja (slika 5). Najveći broj indeksiranih zbornika radova publiciranih u Republici Hrvatskoj je iz područja ekonomije telekomunikacija, građevinarstva, energije i poljoprivrede, dok su radovi objavljeni u inozemnim zbornicima iz područja računarstva, psihologije i psihijatrije, edukacije i informacijskih znanosti.

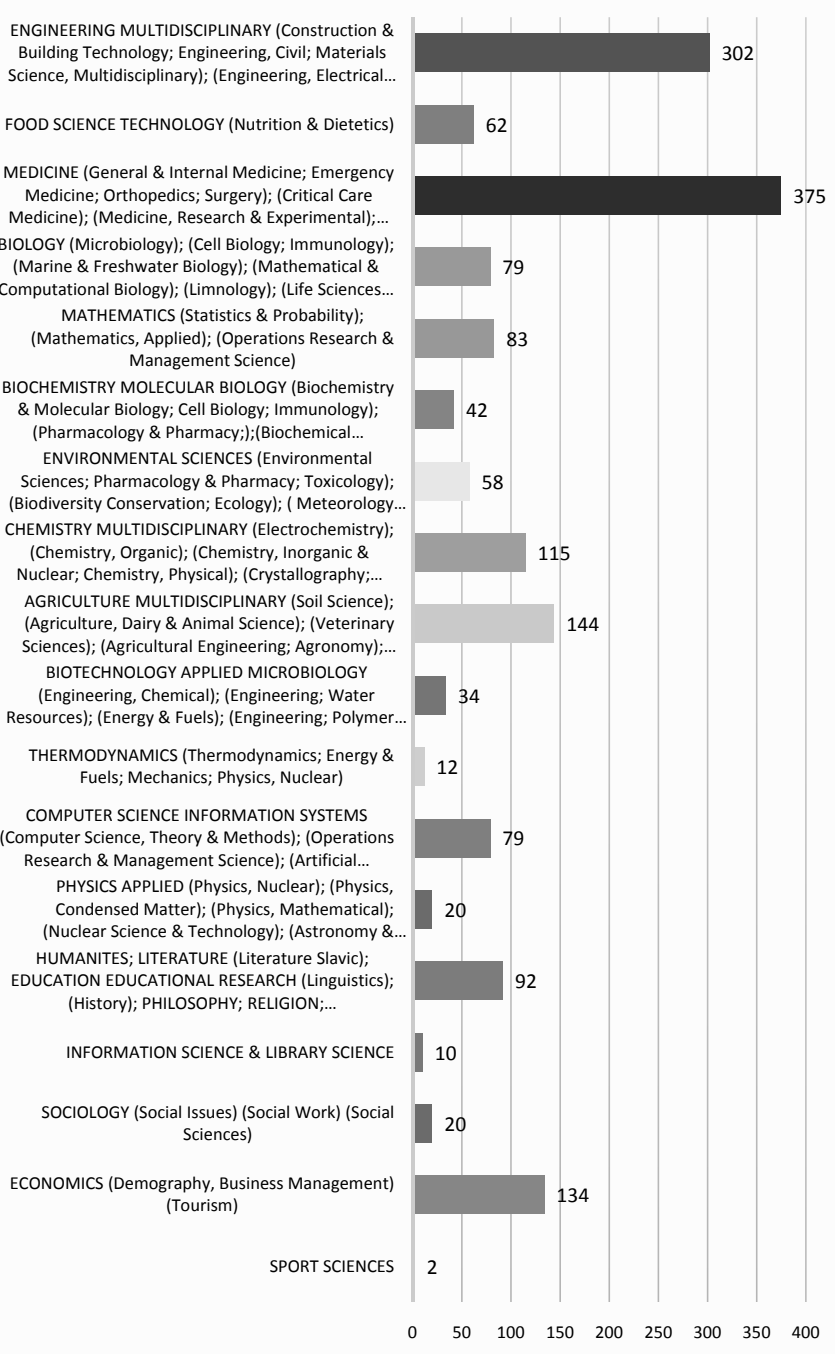

Slika 6. Broj radova razvrstanih po WoS CC-kategorijama (2011.-2015.) 
Slika 6. prikazuje zastupljenost radova autora osječkog sveučilišta s obzirom na WoS CC-kategorije. Kako su radovi u WoS CC-u razvrstani u više od 100 kategorija, radi lakšeg prikaza rezultata kategorije su objedinjene u 18 općenitijih kategorija, pa tako kategorija Chemistry Multidisciplinary objedinjuje kategorije Electrochemistry; Chemistry, Organic; Chemistry, Inorganic \& Nuclear; Chemistry, Physical; Chemistry, Medicinal; Crystallography; Spectroscopy; Chemistry, Analytical; Pharmacology \& Pharmacy; Instruments Instrumentation. Kategoriji MEDICINE pridruženi su radovi koje pripadaju kategorijama: General \& Internal Medicine; Emergency Medicine; Orthopedics; Surgery; Critical Care Medicine; Medicine, Research \& Experimental; Peripheral Vascular Disease; Dentistry, Oral Surgery \& Medicine; Pediatrics; Otorhinolaryngology; Cardiovascular System \& Cardiology; Hematology; Clinical Neurology; Neurosciences; Geriatrics \& Gerontology; Oncology; Endocrinology \& Metabolism; Nursing; Pathology; Gastroenterology \& Hepatology; Physiology; Ophthalmology; Medicine, Legal; Anthropology; Radiology, Nuclear Medicine \& Medical Imaging; Infectious Diseases; Anesthesiology; Respiratory System; Transplantation; Urology \& Nephrology; Psychiatry; Medical Laboratory Technology; Dermatology; Reumathology; Anatomy; Pharmacology \& Pharmacy; Rehabilitation; Substance Abuse; Public, Environmental \& Occupational Health... (slika 6).

Prethodno je navedeno da su u WoS CC-u zastupljeniji radovi autora iz STEM-područja u odnosu na radove autora iz društvenih i humanističkih područja te umjetničkog područja, pa je tako i analizom kategorija pojedinog rada utvrđeno da je najveći broj radova iz kategorija: Medicine (375), Engineering Multidisciplinary (302), Agriculture Multidisciplinary (144)... (slika 6). U kategoriji Economics nalaze se 134 rada, što se može objasniti činjenicom sve većeg uključivanja časopisa iz društvenih i humanističkih područja u WoS CC, a među njima je i nekoliko hrvatskih ekonomskih časopisa, kao i zbornika radova sa skupova.

\section{Zaključak}

Autori Sveučilišta Josipa Jurja Strossmayera u Osijeku u razdoblju od 2011. do 2015. godine publicirali su 1663 rada. Najviše publiciranih radova ubraja se u izvorne znanstvene radove, konferencijska priopćenja te sažetke sa skupova. Analizom radova po godinama publiciranja utvrđen je trend porasta broja radova. Najveći broj radova pripada WoS CC-kategorijama Medicine (375), Engineering Multidisciplinary (302) te Agriculture Multidisciplinary (144), što je sukladno broju autora pojedinih sastavnica Sveučilišta Josipa Jurja Strossmayera u Osijeku. Postavljena hipoteza ovoga rada bila je da je produktivnost autora Sveučilišta Josipa Jurja Strossmayera u Osijeku u stalnom porastu, što se analizom dobivenih rezultata i potvrdilo.

Stalni porast broja indeksiranih radova može se obrazložiti i shvaćanjem autora da je objavljivanje radova u prestižnim, renomiranim časopisima vrlo važno 
kako radi napredovanja pojedinaca u znanstvenome i akademskom sustavu tako i radi financijskih potpora znanstvenim projektima te rangiranja akademske i znanstvene ustanove. Također, jedan od razloga povećanja objavljivanja na osječkom sveučilištu može biti $i$ to što je povećana mobilnost autora te njihova suradnja $s$ autorima iz cijelog svijeta.

Ovakva istraživanja trebaju se provoditi sustavno kako bi se pratila znanstvena publicistika Sveučilišta kao cjeline, bez obzira na to što sastavnice pripadaju različitim znanstvenim područjima.

\section{LITERATURA}

Bibliometrija. // Proleksis enciklopedija. [citirano: 2017-05-03] Dostupno na http://proleksis.lzmk.hr/11019/

Brajenović Milić, Bojana. Bibliometrijski pokazatelji znanstvenog odjeka autora i časopisa. // Medicina fluminensis 50, 4(2014.), 425-432. Dostupno i na http://hrcak.srce. $\mathrm{hr} / 129784$ [citirano: 2017-05-03].

Citation statistics: International Mathematical Union report. 2008. [citirano: 2017-05-03] Dostupno na http://www.mathunion.org/fileadmin/IMU/Report/CitationStatistics.pdf

Clarivate Analytics. [citirano: 2017-05-22] Dostupno na http://clarivate.com/about-us/ what-we-do/

Clarivate Analytics: master journal list - journal list. [citirano: 2017-05-03] Dostupno na http://ip-science.thomsonreuters.com/cgi-bin/jrnlst/jlresults.cgi?PC=MASTER1

Corrall, Sheila; Mary Anne Kennan; Waseem Afzal. Bibliometrics and research data management services: emerging trends in library support for research. // Library Trends 61, 3(2013), 636-674

History of citation indexing. [citirano: 2017-05-22] Dostupno na http://wokinfo.com/ essays/history-of-citation-indexing/?_ga=2.73581585.2047322992.1495455670616265103.1486463420

In memoriam: dr. Eugene Garfield : September 16, 1925 - February 26, 2017. [citirano: 2017-05-22] Dostupno na http://clarivate.com/dr-garfield/?_ga=1.236437830.6162 65103.1486463420

Jokić, Maja. H-indeks kao novi scientometrijski indikator. // Biochemia medica 19, 1(2009), 5-9. Dostupno i na http://hrcak.srce.hr/index.php?show=clanak\&id_clanak_jezik=51302 [citirano: 2017-05-03]. 
Jokić, Maja; Krešimir Zauder; Srebrenka Letina. Karakteristike hrvatske nacionalne i međunarodne znanstvene produkcije u društveno-humanističkim znanostima i umjetničkom području za razdoblje 1991-2005. Zagreb : Institut za društvena istraživanja, 2012. [citirano: 2017-05-03] Dostupno na http://idiprints.knjiznica.idi.hr/10/1/Karakteristike $\% 20$ hrvatske $\% 20$ nacionalne $\% 20 \mathrm{i} \% 20 \mathrm{me} \% \mathrm{C} 4 \% 91$ unarodne $\% 20 \mathrm{znan}$ stvene \%20produkcije\%20u\%20dru\%C5\%A1tveno-humanisti\%C4\%8Dkim $\% 20$ znanostima\%20i\%20umjetni\%C4\%8Dkom\%20podru\%C4\%8Dju\%20za\%20razdoblje\%201991-2005.pdf

Jokić, Maja; Josip Stepanić; Boris Kamenar; Vlatko Silobrčić. Research output of Croatian Universities from 1996 to 2004, registered by the Science citation indeks-expanded. // Interdisciplinary Description of Complex Systems: INDECS 4, 1(2006), 44-50. [citirano: 2017-05-09] Dostupno na http://hrcak.srce.hr/index.php?show=clanak\&id_clanak_jezik=114125

Macan, Bojan; Jelka Petrak. Bibloimetrijski pokazatelji za procjenu kvalitete znanstvenih časopisa. // Hrvatski znanstveni časopisi : iskustva, gledišta, mogućnosti / ur. Ivana Hebrang Grgić. Zagreb : Školska knjiga, 2015. Str. 37-53.

Pehar, Franjo. Od statističke bibliografije do bibliometrije : povijest razvoja kvantitativnog pristupa istraživanju pisane riječi. // Libellarium 3, 1(2010), 1-28. Dostupno i na http:/hrcak.srce.hr/index.php?show=clanak\&id_clanak_jezik=110191 [citirano: 2017-05-03].

Portal elektroničkih izvora za hrvatsku akademsku i znanstvenu zajednicu. [citirano: 2017-05-03] Dostupno na http://baze.nsk.hr/baza/web-science/

Stojanovski, Jadranka. Hrvatski časopisi u WoS CC, CC, JCR i Scopus bazama podataka za 2015. [citirano: 2017-05-03] Dostupno na https://lib.irb.hr/web/hr/vijesti/ item/1893-croatian_journals_wos_cc_scopus_databases_2015.html Stojanovski, Jadranka. Metrika znanstvene publicistike - istina, mitovi i zablude. // Kemija u industriji 59, 4(2010), 179-186. Dostupno i na http://hrcak.srce.hr/index.php?show=clanak\&id_clanak_jezik=77493 [citirano: 2017-05-03].

Stojanovski, Jadranka. (R)evolucija znanstvenih časopisa. // Hrvatski znanstveni časopisi : iskustva, gledišta, mogućnosti / ur. Ivana Hebrang Grgić. Zagreb : Školska knjiga, 2015. Str. 55-76.

Sveučilište Josipa Jurja Strossmayera u Osijeku: sastavnice. [citirano: 2017-03-05] Dostupno na https://www.unios.hr/o-sveucilistu/sastavnice/

Sveučilište u Dubrovniku. Namjensko financiranje znanstvene djelatnosti. [citirano: 2017-05-03] Dostupno na http://www.unidu.hr/odjeli.php?idizbornik=919

Sveučilište u Splitu. Namjensko financiranje znanstvene djelatnosti. [citirano: 201705-03] Dostupno na http://www.unist.hr/LinkClick.aspx?fileticket=ZdfCFGu2 $18 \% 3 \mathrm{~d} \&$ tabid $=1580 \&$ portalid $=0 \& \mathrm{mid}=2837$

Sveučilište u Zagrebu. Namjensko financiranje znanstvene djelatnosti. [citirano: 201705-03] Dostupno na http://www.unizg.hr/istrazivanje/istrazivanje-i-inovacije/finan- 
ciranje-istrazivanja/namjensko-visegodisnje-institucijsko-financiranje-znanstvene-djelatnosti/

Vrana, Radovan. Vrednovanje znanstvenog rada. // Vjesnik bibliotekara Hrvatske 54, 1-2(2011), 172-192. Dostupno i na http://hrcak.srce.hr/index.php?show=clanak\&id clanak_jezik=119700 [citirano: 2017-05-03].

Web of Science. Intelligent results, brilliant connections : brochure. [citirano: 2017-0503] Dostupno na http://ipscience.thomsonreuters.com/product/web-of-science/

Web Of Science Core Collection : descriptive document. 2016. [citirano: 2017-05-23] Dostupno na http://clarivate.libguides.com/ld.php?content_id=29366073 